\title{
Ecosystem structure and processes at Kaloko Honokōhau, focusing on the role of herbivores, including the green sea turtle Chelonia mydas, in reef resilience
}

\author{
Colette C. C. Wabnitz ${ }^{1, *}$, George Balazs ${ }^{2}$, Sallie Beavers ${ }^{3}$, Karen A. Bjorndal ${ }^{4}$, \\ Alan B. Bolten ${ }^{4}$, Villy Christensen ${ }^{1}$, Stacy Hargrove ${ }^{2}$, Daniel Pauly ${ }^{1}$ \\ ${ }^{1}$ Fisheries Centre, AERL, University of British Columbia, 2202 Main Mall, Vancouver, British Columbia V6T 1Z4, Canada \\ ${ }^{2}$ Marine Turtle Research Program, NOAA, National Marine Fisheries Service, Pacific Islands Fisheries Science Center, \\ 2570 Dole Street, Honolulu, Hawai'i 96822-2396, USA \\ ${ }^{3}$ National Park Service, Kaloko-Honokōhau National Historical Park, 73-4786 Kanalani St., \#14, Kailua Kona, \\ Hawai'i 96740, USA
}

${ }^{4}$ Archie Carr Center for Sea Turtle Research, and Department of Biology, PO Box 118525, University of Florida, Gainesville, Florida 32611, USA

\begin{abstract}
The formal protection of the Hawaiian green turtle Chelonia mydas in the 1970s has led to significant increases in the number of individuals recorded throughout the archipelago. Reduced growth rates and poor body condition of individuals at a number of foraging sites, including KalokoHonokōhau National Historical Park (Kaloko), suggest that some aggregations have reached carrying capacity. To better understand the ecological structure and processes of the reef system at the park, we developed an ecosystem model that synthesized available data on Kaloko for the year 2005 and included 26 groups, spanning the entire trophic web. Model results showed that the combined grazing pressure of the different herbivore functional groups (i.e. reef fish, sea urchins, and green turtles) in Kaloko matched total algal production. Sea urchins exerted the strongest control over algal resources, partly because of their large biomass in park waters. Results confirmed that the Kaloko green turtle aggregation has reached carrying capacity. Green turtles help maintain low algal cover, and thus resilience of reefs in the face of disturbance, and should be explicitly included in studies of ecosystem dynamics on reefs. Our work also provides a 'current-condition' baseline for Kaloko, and a valuable tool for the assessment of the future marine ecosystem impacts of projected urban expansion plans around the park.
\end{abstract}

KEY WORDS: Marine turtles $\cdot$ Ecosystem-based management $\cdot$ Ecopath $\cdot$ Coral reef $\cdot$ Herbivory Phase shift $\cdot$ Nutrient enrichment $\cdot$ Kona coast $\cdot$ Hawaii

\section{INTRODUCTION}

Grazing by herbivores is one of the major processes structuring benthic coral reef communities. Studies highlighting the role of herbivores in promoting reef resilience and recovery to coral-dominated states, where disturbance has led to increased algal biomass (e.g. Bellwood et al. 2004), have focused almost exclusively on fish and sea urchins (Hay 1984a, Carreiro-Silva \& McClanahan 2001, Mumby et al. 2006a, Paddack et al. 2006, Albert et al. 2008). Numerous Caribbean reefs have transitioned from 
coral to algal-dominated states (Gardner et al. 2003) following either a dramatic reduction in fish stocks that limited the distribution, abundance, and production of algae (Ogden \& Lobel 1978, Hay 1981, Lewis 1986), or the region-wide loss to disease of an important echinoid herbivore (Diadema antillarum) in systems that had previously seen a shift from fishdominated to echinoid-dominated herbivory (Lessios 1988, Mumby et al. 2006b). At some locations, increased anthropogenic nutrient loading has further increased the abundance of primary producers (Burkepile \& Hay 2006, Littler \& Littler 2007). Few studies have looked at the role of green sea turtles Chelonia mydas in maintaining coral reef resilience. This is understandable in the Caribbean where green turtles mostly forage on seagrass (Bjorndal 1980, Mortimer 1981, Thayer et al. 1984) and thus predominantly have an indirect impact on the trophodynamics of reef ecosystems (Valentine et al. 2002, Heck \& Valentine 2006, Wabnitz 2010).

In Hawai'i, situated in the North Pacific, although the majority of reefs are not as severely impacted as those throughout the Caribbean region (Brainard et al. 2002, Waddell \& Clarke 2008), several locations have shown increasing signs of stress as a result of mounting anthropogenic pressures on the coastal zone through development and runoff, tourism and recreation activities, and overfishing (Grigg 1994, Hunter \& Evans 1995, Friedlander et al. 2008, Williams et al. 2008). Unlike in the Caribbean region, green turtles in Hawai'i feed primarily on algal species that commonly occur on the reef (McCutcheon et al. 2003, McDermid et al. 2007, Arthur \& Balazs 2008, Russell \& Balazs 2009). They may therefore play a direct role in maintaining the resilience of reef ecosystems. The fact that green turtles feed on non-native algae, Acanthophora spp. and Hypnea spp. (Doty 1961, Russell 1992, Russell \& Balazs 1994, Arthur \& Balazs 2008, Russell \& Balazs 2009), further highlights their contribution to the promotion of reef resilience.

Since turtle harvesting ended in the late 1970s (Witzell 1994), an approximately linear increase in the abundance of nesting females has occurred at French Frigate Shoals (Balazs \& Chaloupka 2004a, 2006), which accounts for $>90 \%$ of all nesting within the Hawaiian Archipelago (Balazs 1980). This increase in abundance is interpreted as a recovery trend because the Hawaiian nesting population has been continuously monitored using dependable methodology for several decades (Balazs \& Chaloupka 2004a, Chaloupka et al. 2008) and is considered 'self-contained' (Dutton et al. 2008). Population trends at a number of foraging grounds that also have been subject to long-term monitoring seem to mirror this trajectory (Chaloupka \& Balazs 2007).
An understanding of the ecological role of green turtles as grazers on reefs requires a process-oriented approach that assesses, preferably quantitatively, the relative contributions of all herbivore functional groups (i.e. fish, sea urchins, and green turtles). Such an approach is currently lacking, though it may provide significant insights into the need for, and consequences of, improved turtle conservation and management.

Ecological modeling has developed ways to mathematically describe the complexity and non-linear behavior of ecological systems. Ecopath with Ecosim is a freely available, widely used software for describing the structure of ecosystems and their food webs. It was recently named as one of the 10 major scientific breakthroughs in the $200 \mathrm{yr}$ history of the US National Oceanographic and Atmospheric Administration (NOAA i see http://celebrating200years.noaa.gov/ breakthroughs/welcome.html). Rather than providing outputs at the population level of biological organization, typical of many models, the Ecopath with Ecosim approach provides outputs at the ecosystem level, reflecting food-web linkages, energy cycling, and changes in biomass of each species group defined in the model (Christensen 2008). Although determining carrying capacity of a system has been highlighted as one of the uses of this software, few studies have explored this aspect through the use of Ecopath with Ecosim (but see Christensen \& Pauly 1998).

We developed an Ecopath trophic model to investigate the role that green turtles play in the coral reef ecosystem of Kaloko-Honokōhau National Historical Park (Kaloko). Located on the west coast of Hawai'i Island (the 'Big Island'; Fig. 1), the park supports a healthy and relatively diverse coral habitat with little evidence of non-native species of macroalgae or diseased coral (Gibbs et al. 2007). It has low fish biomass, but high fish diversity (Parrish et al. 1990, Beets et al. 2010). The park also has a resident foraging population of immature green turtles that has been the subject of a mark-recapture study by the NOAA National Marine Fisheries Service and the US National Park Service since 1999. Three lines of evidence suggest that this foraging population has reached carrying capacity: (1) The significant increase in green turtle abundance throughout the archipelago over the last 10 to $20 \mathrm{yr}$ has been associated with a significant decrease in somatic growth rates at many foraging grounds around the Main Hawaiian Islands, including the west coast of the Big Island (Balazs \& Chaloupka 2004b), possibly the result of density dependence (Bjorndal et al. 2000); (2) Field measurements of body volume and mass as an index of body condition have shown that turtles at foraging locations near Kaloko have lower body condition indices than green turtles at other sites 


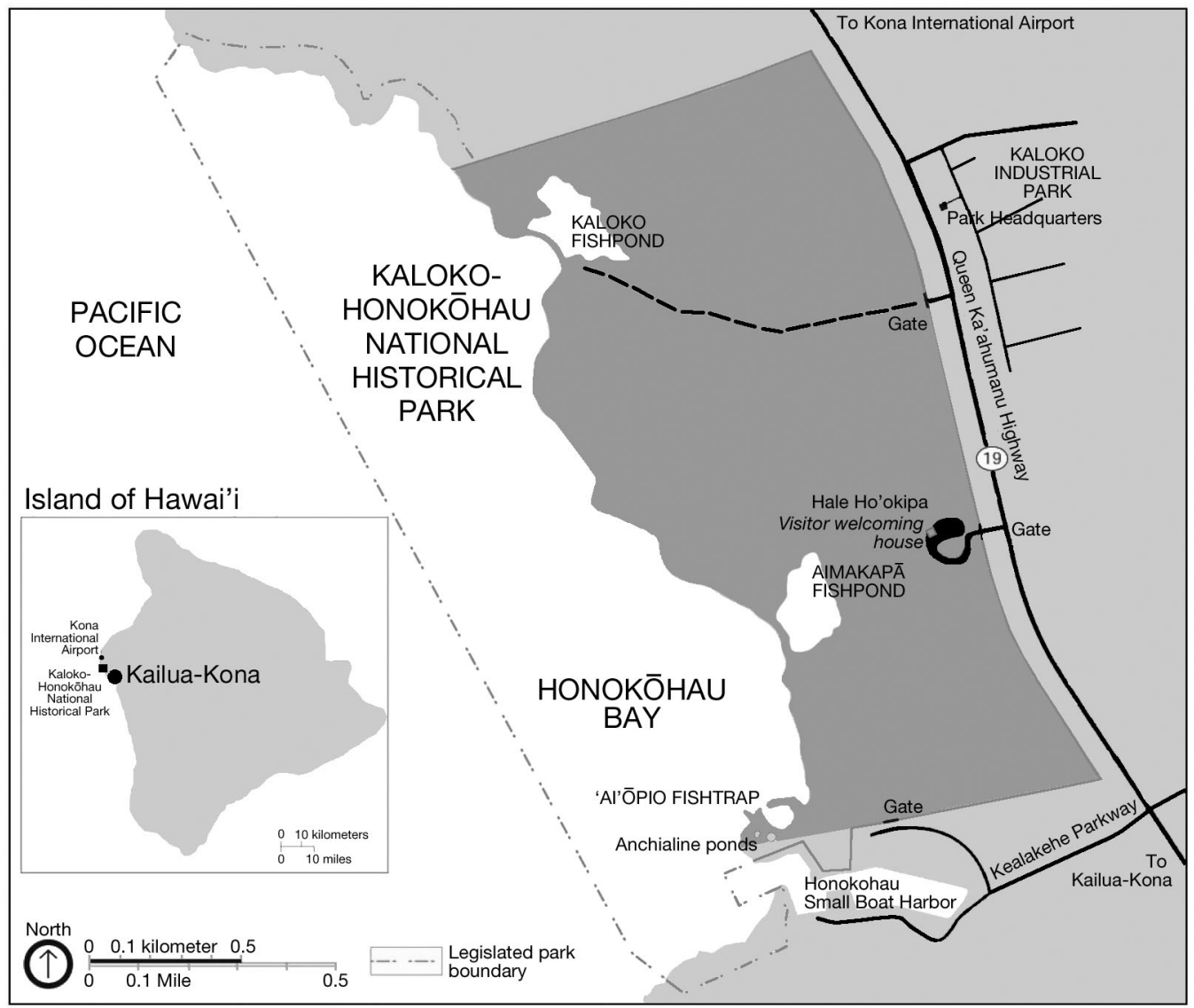

Fig. 1. Kaloko-Honokōhau National Historical Park (Kaloko), located on the west coast of the Big Island, Hawai'i, USA

on the Island of Hawai'i (Kubis et al. 2008); and (3) Recent necropsy reports cite emaciation as a probable contributor in the death of a number of green turtles found stranded at foraging locations along the west coast of the Hawai'i Island (or Kona Coast) (Work 2007, 2008a,b).

The trophic model is also intended as a 'baseline' of ecosystem state for Kaloko prior to major developments projected for areas around the park. Concern has been expressed over the future health of Kaloko's coastal resources given proposed plans for the development of lands adjacent to the south boundary of the park, including a $300 \%$ expansion of a small-boat harbor, and construction of hotels, condominiums, and a light industrial park (Gibbs et al. 2007). Expected impacts include a reduction in groundwater flow, an important feature at Kaloko, with a concomitant increase in groundwater loads of sediment, nutrient, and chemical pollutants (Oki et al. 1999, Paytan et al. 2006, Johnson et al. 2008).

The goals of this study were therefore 3-fold: (1) To develop an ecosystem model of the marine portion of the park, synthesizing available data and describing the ecological structure and processes of the reef sys- tem at Kaloko; (2) To ascertain whether Kaloko green turtles are at carrying capacity, by determining whether grazing by green turtles and other reef herbivores matches overall algal production; (3) To provide the management community with a tool that can simulate the effects of increased urban development in the Kaloko area, as well as compare the outcomes of a range of potential management scenarios.

\section{MATERIALS AND METHODS}

Study area. Kaloko-Honokōhau National Historical Park was established in 1978 and spans $5.17 \mathrm{~km}^{2}$, of which $2.48 \mathrm{~km}^{2}$ is marine (Gibbs et al. 2007). The park is bordered to the south by the Honokōhau Small-Boat Harbor, and there are large scale industrial/commercial developments to the east. The terrestrial portion includes more than 180 anchialine (brackish) pools, 2 large ponds and wetlands modified for fish production by early Hawaiians, and a fish trap (Kaloko, 'Aimakapā and 'Ai'ōpio respectively; Fig. 1). The coastal waters and reefs of Kaloko are within the West Hawai'i Fisheries Management Area and are currently 
managed by the State of Hawai'i. The legislated park boundary extends offshore for about $1000 \mathrm{~m}$ at the widest point and to maximum depths of ca. $70 \mathrm{~m}$ (Parrish et al. 1990). Past this boundary the seabed drops off to depths $>180 \mathrm{~m}$. Approximately $73 \%$ of the marine section of the park is hardbottom. The remaining $27 \%$ comprises unconsolidated sediment and artificial/historical features. Most of the hardbottom area has 10 to $<50 \%$ coral cover, and ca. $12 \%$ has 50 to $100 \%$ coral cover (Gibbs et al. 2007). Benthic habitats are considered relatively healthy, with no signs of diseased corals or non-native algal species (Marrack et al. 2009, Weijerman et al. 2009). Low sedimentation rates and the presence of relatively high coral cover in protected locations suggest that currently, the reef habitat in Kaloko is primarily controlled by natural waveinduced stresses (DeVerse 2006).

Modeling approach. We used Ecopath with Ecosim (EwE), software version 5.1.208 (Christensen \& Walters 2004, Christensen et al. 2005, www.ecopath.org). The Ecopath component of any EwE model provides a quantitative representation of an ecosystem for a defined time period. In other words, it is a snapshot of the resources in an ecosystem and their interactions, represented by trophically linked mass-balanced biomass 'pools' (Polovina 1984, Christensen \& Pauly 1992). The biomass pools, hereafter referred to as functional groups, consist of a single species, or species groups representing ecological guilds. The idea behind the mass-balance approach is that 'at any time within the system, and within the elements of that system, the amounts of matter that flow in must balance the amount that goes out plus the change in biomass' (Pauly \& Christensen 2002 p. 215). Ecopath therefore operates under 2 main assumptions:

(1) That biological production within a functional group equals the sum of mortalities (i.e. on an annual basis, biomass and energy in an ecosystem are conserved; Walters et al. 1997, Walters \& Martell 2004). This relationship can be expressed as follows:

$$
\begin{gathered}
B_{i} \cdot(P / B)_{i}=\sum_{j=1} B_{j} \cdot(Q / B)_{j} \cdot D C_{j i}+Y_{i}+E_{i}+B A_{i} \\
+B_{i} \cdot(P / B)_{i} \cdot\left(1-E E_{i}\right)
\end{gathered}
$$

where $B_{i}$ and $B_{j}$ are biomasses of prey (i) and predator $(j)$, respectively; $(P / B)_{i}$ is the production to biomass ratio, equivalent to total mortality $(Z)$ under most circumstances (Allen 1971); $(Q / B)_{j}$ is the food consumption per unit biomass of $(j) ; D C_{j i}$ is the fraction of prey (i) in the average diet of predator $(j) ; Y_{i}$ is the total fishery catch rate of group (i); $E_{i}$ is the net migration rate (emigration - immigration); $B A_{i}$ is the biomass accumulation rate of group $(i)_{;}$and $E E_{i}$ is the ecotrophic efficiency, defined as the fraction of production that is consumed within the system or is removed by fishers; and
(2) That consumption within a group equals the sum of production, respiration, and unassimilated foods. This relationship can be expressed as follows:

$$
\begin{gathered}
B \cdot(Q / B)=B \cdot(P / B)+(1-G S) \cdot Q-(1-T M) \cdot P \\
+B \cdot(Q / B) \cdot G S
\end{gathered}
$$

where GS is the proportion of unassimilated food, and $T M$ is the trophic mode expressing the degree of heterotrophy of groups represented within the system, with 0 representing autotrophs, 1 heterotrophs, and intermediate values facultative consumers.

Ecopath then uses a set of algorithms to simultaneously solve $\mathrm{n}$ linear equations of the form in Eq. (1), where $\mathrm{n}$ is the number of functional groups. For each functional group, 3 of the basic parameters: $B_{i,}(P / B)_{i r}$ $(Q / B)_{i}$ or $E E_{i}$ must be known, in addition to the fisheries yield $\left(Y_{i}\right)$, and the diet composition. Units of the model are expressed in $\mathrm{t} \mathrm{km}^{-2} \mathrm{yr}^{-1}$ wet weight for flows and $\mathrm{t} \mathrm{km}^{-2}$ wet weight for biomasses. Production per unit biomass $(P / B)$ and consumption per unit biomass $(Q / B)$ have the dimension $\mathrm{yr}^{-1}$. For a review of EwE's capabilities and limitations see Christensen \& Walters (2004), Plaganyi \& Butterworth (2004), and Plaganyi (2007).

To balance the model, changes were first made to the diet matrix, as diet compositions represent only snapshots of the feeding habits of individual species and are likely to be relatively variable based on location and time periods of data collection. The model required only minor adjustments and was considered balanced when: (1) The model produced realistic ecotrophic efficiencies $(E E<1)$; (2) Values of the production to consumption ratio $(P / Q)$ for functional groups were between 0.05 and 0.35 , with the exception of groups with fast growth rates (higher ratios), and top predators (lower values) (Christensen et al. 2005).

Model parameters and functional groups. The model represented an annual average situation of ecosystem conditions in the marine portion only (i.e. to the exclusion of the anchialine pools, fish ponds, and fish traps) of Kaloko in 2005. We defined a total of 26 functional groups, 8 of which were fish, spanning the main trophic components of the ecosystem (including detritus; Table 1, Fig. 2). The 8 fish groups represented the aggregation, based on ecological and biological similarities (e.g. diet, size, habitat, mortality), of 106 fish species recorded during underwater visual census studies (Beets et al. 2010; see Table S1 in the supplement at www.int-res.com/articles/suppl/m420p027 supp.pdf).

Biomass estimates for individual species were based on values from field studies, local expert opinion, or from the literature. For species with data reported only from selected habitats, biomass values were extrapolated to the entire park by calculating an area- 
Table 1. Trophic parameters for all functional groups of the balanced Kaloko model. Model outputs are presented in bold. $B$ : biomass; $T L$ : trophic level; $P / B$ : productivity to biomass ratio; $Q / B$ : consumption rate; $E E$ : ecotrophic efficiency; $P / Q$ : production to consumption ratio or gross efficiency; $P / R$ : production to respiration ratio; MIF: mobile invertebrate feeders; SIF: sessile invertebrate feeders; Zoo: zooplanktivorous species; CCA: crustose coralline algae; turf $\mathrm{LB}_{\mathrm{LB}}$ t turf algae growing on the nearshore lava bench

\begin{tabular}{|c|c|c|c|c|c|c|c|c|c|}
\hline & Group name & $T L$ & $\begin{array}{c}B \\
\left(\mathrm{t} \mathrm{km}^{-2}\right)\end{array}$ & $\begin{array}{l}P / B \\
\left(\mathrm{yr}^{-1}\right)\end{array}$ & $\begin{array}{l}Q / B \\
\left(\mathrm{yr}^{-1}\right)\end{array}$ & $E E$ & $P / Q$ & $P / R$ & $\begin{array}{c}\text { Catch } \\
\left(\mathrm{t} \mathrm{km} \mathrm{km}^{-2} \mathrm{yr}^{-1}\right)\end{array}$ \\
\hline 1 & Spinner dolphins & 3.21 & 2.7400 & 0.151 & 11.519 & 0.007 & 0.013 & 0.017 & - \\
\hline 2 & Monk seals & 3.89 & 0.1790 & 0.121 & 11.508 & 0.033 & 0.011 & 0.013 & - \\
\hline 3 & Sea birds & 3.17 & 0.0024 & 0.127 & 76.515 & 0.012 & 0.002 & 0.002 & - \\
\hline 4 & Rays & 3.15 & 4.2330 & 0.200 & 3.100 & 0.002 & 0.065 & 0.065 & - \\
\hline 5 & Sharks and jacks & 3.53 & 0.0700 & 1.058 & 5.100 & 0.453 & 0.207 & 0.350 & 0.030 \\
\hline 6 & Hawksbill sea turtles & 3.18 & 0.0540 & 0.100 & 3.500 & 0.066 & 0.029 & 0.029 & - \\
\hline 7 & Green sea turtles & 2.00 & 1.5910 & 0.109 & 6.764 & 0.039 & 0.016 & 0.021 & - \\
\hline 8 & Reef fishes - piscivores & 3.39 & 1.7295 & 0.615 & 6.121 & 0.527 & 0.100 & 0.144 & 0.003 \\
\hline 9 & Reef fishes - herbivores & 2.02 & 20.3350 & 1.400 & 27.149 & 0.205 & 0.052 & 0.069 & 0.162 \\
\hline 10 & Reef fishes - corallivores & 2.60 & 0.5417 & 2.100 & 12.918 & 0.547 & 0.163 & 0.255 & - \\
\hline 11 & Reef fishes - detritivores & 2.00 & 2.2598 & 1.900 & 32.272 & 0.282 & 0.059 & 0.079 & 0.018 \\
\hline 12 & Reef fishes - MIF & 3.13 & 9.7610 & 0.950 & 8.108 & 0.394 & 0.117 & 0.172 & 0.130 \\
\hline 13 & Reef fishes - SIF & 2.84 & 0.5440 & 1.700 & 9.581 & 0.224 & 0.177 & 0.285 & - \\
\hline 14 & Reef fishes - Zoo & 2.85 & 3.0460 & 1.450 & 13.378 & 0.585 & 0.108 & 0.157 & 0.004 \\
\hline 15 & Urchins & 2.00 & 280.0000 & 0.484 & 8.547 & 0.056 & 0.057 & 0.076 & - \\
\hline 16 & Crown of thorns & 2.59 & 0.1170 & 0.411 & 9.000 & 0.007 & 0.046 & 0.061 & - \\
\hline 17 & Benthic invertebrates & 2.18 & 42.5381 & 2.910 & 15.250 & 0.950 & 0.191 & 0.313 & - \\
\hline 18 & Corals & 1.58 & 130.0000 & 0.140 & 2.100 & 0.594 & 0.067 & 0.075 & - \\
\hline 19 & Octocoral & 2.07 & 2.9000 & 0.200 & 4.630 & 0.484 & 0.043 & 0.054 & - \\
\hline 20 & Macroalgae & 1.00 & 22.6910 & 9.824 & - & 0.925 & - & - & - \\
\hline 21 & $\mathrm{CCA}$ & 1.00 & 37.8180 & 1.770 & - & 0.358 & - & - & - \\
\hline 22 & Turf algae & 1.00 & 128.7800 & 19.000 & - & 0.942 & - & - & - \\
\hline 23 & $\operatorname{Turf}_{\mathrm{LB}}$ & 1.00 & 3.0650 & 25.000 & - & 0.921 & - & - & - \\
\hline 24 & Zooplankton & 2.02 & 1.2400 & 219.000 & 949.000 & 0.979 & 0.231 & 0.625 & - \\
\hline 25 & Phytoplankton & 1.00 & 3.2900 & 325.458 & - & 0.984 & - & - & - \\
\hline 26 & Detritus & 1.00 & 100.0000 & - & - & 0.694 & - & - & - \\
\hline
\end{tabular}

weighted biomass for each species relative to the proportion that each benthic habitat category covered within park waters (the latter based on Gibbs et al. 2007). For instances where $P / B$ was equal to only natural mortality $(M)$, estimates were taken directly from the literature, or derived using the empirical formula of Pauly (1980). For exploited species, fishing mortality values were based on Friedlander \& Parrish (1997) (see below). Where possible, the consumption rate for each functional group was obtained through field studies; otherwise it was estimated from empirical equations such as those available in FishBase (www.fishbase.org) for all finfish. The diet matrix was constructed using data from field studies in Hawai'i, preferentially the west coast of the Big Island. Where no such data were available, the matrix was complemented with information obtained from the literature for the same species in similar ecosystems. Details of data sources and estimation methods for all parameters are given in Table S2 in the supplement.

Fisheries. Kaloko's waters were designated as a Fish Replenishment Area on 31 December 1999, effectively banning the harvest of live reef fish for the aquarium trade, in response to declines of species targeted by collectors (Tissot et al. 2004). Biomass of targeted species may have responded to the closure, and because fishing pressure for ornamentals has been removed, $P / B$ was set to $M$ for all formerly collected species.

The park is a popular location for subsistence fishing and shoreline gathering, traditional activities that are permitted as long as they are consistent with state law and park mandates (i.e. with legal fishing gear for personal consumption; DeVerse 2006). Harvesting is done primarily from shore using several methods, such as throw nets, spear, and pole and line fishing. Gill, or 'lay' netting, a serious threat to marine resources including marine mammals and sea turtles, was restricted within park waters in August 2005 to locally constructed, handmade nets of natural fibers. The State of Hawai'i does not have recreational and subsistence permitting or reporting requirements (Friedlander \& Parrish 1997), despite surveys in the late 1980s indicating that 19 to $35 \%$ of residents fish (Smith 1993), and recent studies concluding that these fisheries dominate the catch of coral reef species (Zeller et al. 2005, Williams et al. 2008). Although several studies conducted throughout the Hawaiian Archipelago have assessed the importance of fishing impacts on coral reef 


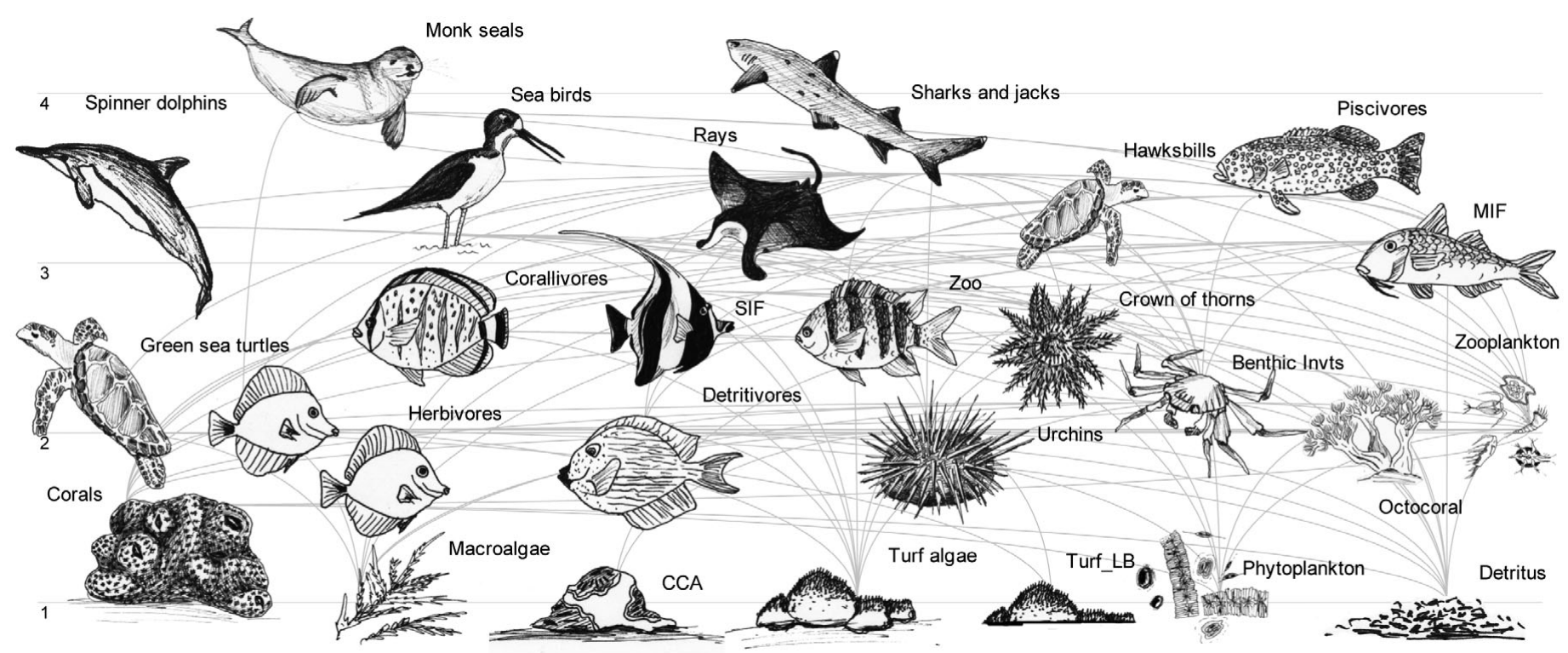

Fig. 2. Trophic flows within the Kaloko reef ecosystem. Each functional group is identified here by an illustration (@ M. Bailey); where relevant, an image of a species representative of its guild is depicted. Images are not drawn to scale or proportional to the group's biomass. The light grey horizontal lines and associated numbers represent trophic levels; lines connecting individual functional groups represent trophic links. Zoo: zooplanktivorous reef fish; MIF: mobile invertebrate feeding reef fish; SIF: sessile invertebrate feeding reef fish; Turf $\mathrm{LB}_{\mathrm{B}}$ : turf algae growing on the nearshore lava bench; $\mathrm{CCA}$ : crustose coralline algae; Benthic Invts: benthic invertebrates

fish assemblages (e.g. Tissot et al. 2004, 2009, Williams et al. 2008, the Hawai'i Division of Aquatic Resources (DAR) unpubl. data in Weijerman et al. 2009), few data exist to quantify fishing mortality along the western shores of the Big Island. In the absence of catch or effort data specific to Kaloko, we assumed catch data to standing stock proportions in the park to be comparable to those in Hanalei Bay, Kauai (Friedlander \& Parrish 1997), and adjusted values to reflect species known to be targeted at Kaloko. As no data were available on macroinvertebrates in Kaloko (with the exception of sea urchins), nor information regarding whether fishing occurs on those groups in the park, no catch was allocated to the 'benthic invertebrates' functional group.

We divided existing fisheries into 2 'fleets,' one targeting 'sharks and jacks' specifically, and a recreational/subsistence fishery representing fishers operating mainly from shore, and targeting small reef fish. We calculated the ratio of catch to standing stock for fish families targeted by fishers from Friedlander \& Parrish (1997), and doubled them, given that fishing pressure is likely to be higher now than it was in 1997 (DAR unpubl. data in Weijerman et al. 2009). We then applied these indices to fish families harvested in Kaloko (E. Brown unpubl. data). For species groups targeted in Kaloko, but for which data were not available from Friedlander \& Parrish (1997), we applied the same value as for fish families in the same functional group. Fishing mortality for individual species/ functional groups was calculated using $F=$ catch/ biomass.

Model analysis, indices, and uncertainty around input data. We quantified total trophic flows within the ecosystem in terms of consumption, production, respiration, exports and imports, and flow to detritus ( $\mathrm{t} \mathrm{km}^{-2} \mathrm{yr}^{-1}$ ). We then used ecological indices as obtained through ecological network analysis (ENA) to evaluate the food web (Wulff et al. 1989, Christensen \& Pauly 1993). ENA is a modeling technique used for understanding the structure and flow of material between components of an ecosystem (Ulanowicz 1997). As integrated in Ecopath, ENA allows for the calculation of ecosystem macro-descriptors that quantify trophic structure, organic matter recycling, and ecosystem size and organization. These descriptors include total system throughput, ascendency, development capacity, and the relative overhead. Throughput describes the size of a system and represents a measure of its metabolism (Christensen \& Pauly 1993). Ascendency integrates both size and organization of a given system (Christensen 1995). The development capacity (C) quantifies the upper limit to ascendency, whereas the system's overhead $(O)$ is complementary to the ascendency and measures the level of 'redundancy' of particular links (Heymans 2003). The relative overhead (O/C ratio) was proposed by Heymans (2003) as an index of the resilience of the system (i.e. an index of the system's ability to withstand disturbance; Ulanowicz 1997). ENA further 
allows the derivation of transfer efficiencies (TE), summarizing the proportion of consumption that is passed up a food web. The TE is the ratio between the production of a given trophic level and the preceding trophic level (Pauly \& Christensen 1995). Finally, we ran the mixed trophic impact (MTI), or ecological input-output, analysis (Ulanowicz \& Puccia 1990), which describes how any functional group impacts, directly and indirectly (i.e. both predatory and competitive interactions), all other functional groups within the food network. In other words, this analysis provides a first-order quantification of the beneficial and negative impacts of one functional group on another (scaled between -1 and 1). The MTI for living groups is calculated by constructing an $\mathrm{n} \times \mathrm{n}$ matrix, where the interaction between the impacting group $(j)$ and the impacted group (i) is represented as follows (Christensen \& Walters 2004):

$$
\mathrm{MTI}_{j i}=D C_{j i}-F C_{i j}
$$

where $D C_{j i}$ as in Eq. (1) above, is the diet composition term expressing how much (i) contributes to the diet of predator $(j)$, and $F C_{i j}$ is a host composition term giving the proportion of the predation on (i) that is due to $(j)$. For detritus groups, the $D C_{j i}$ term in Eq. (3) above is set to 0 .

Any ecosystem model realization requires acknowledging the large amount of data required in its development, and the difficulty in quantifying the flows between the food web's individual functional groups. Functional group dynamics can be verified by fitting model data to actual population trends over time. Such time series data do not exist for Kaloko. To address model uncertainties, probability distributions for all Ecopath input parameters were entered through the 'pedigree' (Funtowicz \& Ravetz 1990) function of Ecopath (Pauly et al. 2000). Using a Monte Carlo re-sampling routine, the 'Ecoranger' module of Ecopath draws random input variables from within the confidence intervals defined for each parameter type in the pedigree tables and uses these as prior probability distributions for all input data. This approach leads to a large number of model realizations that are evaluated for their conformity to user-defined criteria as well as physiological and mass-balance constraints. The results include probability distributions for the estimated parameters along with distributions of parameters in the accepted model realizations. This routine can be run for the model overall, as pedigrees are associated with all input parameters. However, given our primary goal to determine whether green turtles are at carrying capacity at Kaloko we focused on sources of uncertainty associated with: estimates of green turtle biomass, $P / B$, and $Q / B$; the proportion of sea urchins' diet that was derived from turf algae growing on the nearshore lava bench $\left(\operatorname{turf}_{\mathrm{LB}}\right)$; and variability associated with $\operatorname{turf}_{\mathrm{LB}}$ biomass and $P / B$.

\section{RESULTS}

Trophic parameters and the diet matrix for the 26 groups of the final balanced Ecopath model for Kaloko are presented in Tables $1 \& 2$. Trophic flows between all functional groups are depicted in Fig. 2. Sea urchins (Tripneustes gratilla, Echinometra mathaei, Heterocentrotus mammilatus, and Echinothrix spp.) accounted for the largest proportion of total living biomass in the system $(40 \%)$. Green turtles and reef fish groups, including 'sharks and jacks,' only represented 0.2 and $5.5 \%$ of total biomass, respectively. Reef fish functional groups were dominated by herbivorous and mobile invertebrate feeding species. Not surprisingly, consumption by sea urchins had the biggest impact (45\%) on available resources at Kaloko, whereas fish accounted for $14.4 \%$ and green turtles for $0.2 \%$ of total consumption. Total fisheries catches represented less than $1 \%$ of total fish biomass (Table 1). Sharks and jacks were caught in larger quantities compared with their relatively low biomass in the assemblage. Mean trophic level of the total fisheries catch was 2.59 (Table 3).

Ecotrophic efficiency ( $E E$ ) values (the proportion of a functional group's production used within the system) were lowest for some of the highest trophic levels, including 'spinner dolphins,' 'monk seals,' and 'sea birds,' as well as 'crown of thorns starfish,' 'hawksbill turtles,' 'green turtles,' 'sea urchins,' and 'corals' (Table 1). For the first 3 groups, this valuation is due to these species deriving a significant proportion of their food from outside park waters. They were included chiefly to ensure that the model was representative of the system at Kaloko (i.e. to acknowledge that these species occur in the park, and may at some point in the future suffer from indirect effects of park development, even if they do not feed exclusively or primarily in park waters). For the 5 other groups, the low EE values are a result of low predation and fishing pressure being exerted on these species. Fish groups, overall, also had relatively low EE values, with higher values registered by those species pools that were subject to higher fishing mortality. This valuation suggests that the system generates a reasonable amount of surplus secondary production. Indeed, the largest component of the mortality coefficients within the system was due to predation mortalities, with the exception of 'sharks and jacks, ' for which the fishing mortality rate was greater than predation mortality. In contrast, most of the production by the macro- and turf algal groups, 'zooplankton,' 'benthic invertebrates,' and 'phytoplankton' was accounted for through consumption by other trophic groups within the model $(E E>90 \%)$. In other words, sea urchins, herbivorous fish, and green turtles maintained all algae at Kaloko in a cropped state. 


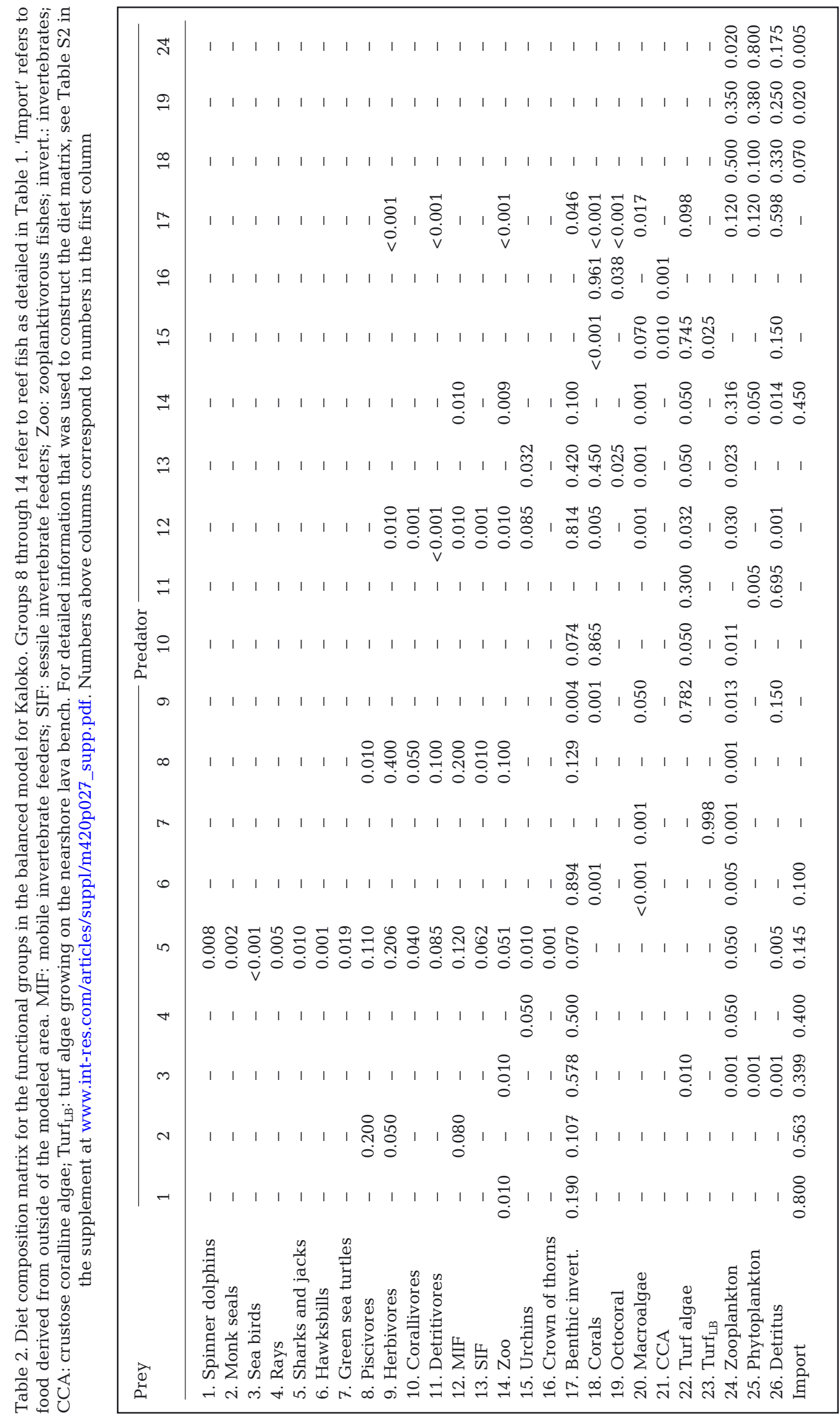


Table 3. Summary of outputs from the ecological network analysis (ENA)

\begin{tabular}{|lrl|}
\hline Sum of all consumption & 5332.03 & $\mathrm{t} \mathrm{km}^{-2} \mathrm{yr}^{-1}$ \\
Sum of all exports & 520.07 & $\mathrm{t} \mathrm{km}^{-2} \mathrm{yr}^{-1}$ \\
Sum of all respiratory flows & 3477.31 & $\mathrm{t} \mathrm{km}^{-2} \mathrm{yr}^{-1}$ \\
Sum of all flows into detritus & 1700.15 & $\mathrm{t} \mathrm{km}^{-2} \mathrm{yr}^{-1}$ \\
Total system throughput & 11030.00 & $\mathrm{t} \mathrm{km}^{-2} \mathrm{yr}^{-1}$ \\
Calculated total net primary production & 3895.09 & $\mathrm{t} \mathrm{km}^{-2} \mathrm{yr}^{-1}$ \\
Total primary production/total respiration & 1.12 & \\
Total biomass (excluding detritus) & 699.53 & $\mathrm{t} \mathrm{km}^{-2}$ \\
Total catches & 0.35 & $\mathrm{t} \mathrm{km}^{-2} \mathrm{yr}^{-1}$ \\
Mean trophic level of the catch & 2.59 & \\
Throughput cycled (excluding detritus) & 54.52 & $\mathrm{t} \mathrm{km} \mathrm{yr}^{-1}$ \\
Finn's cycling index & 6.13 & $\%$ of total throughput \\
Ascendency & 31.50 & $\%$ \\
Relative overhead (O/C) & 68.50 & $\%$ \\
\hline
\end{tabular}

Reef-building corals, octocorals, benthic invertebrates, and zooplanktivorous fish were the main predators of zooplankton, while zooplankton consumed most of the phytoplankton production in the system. Benthic invertebrates were preyed upon mostly by MIF reef fish and species within the benthic invertebrate group itself.

Throughput (total flows) values for each functional group highlighted the importance of turf algae, zooplankton, phytoplankton, and sea urchins in system structure. The high EEs attained for all algal groups indicated that the system was at carrying capacity with respect to grazing, including for green turtles. The pri- mary producers' high EEs were also reflected in the low production/respiration ratio of 1.12 for the system overall (Table 3).

Focusing on green turtles, urchins, and herbivorous reef fish in the system only, the MTI routine highlighted the resource competition both within and among all 3 groups (Fig. 3). Sea urchins were responsible for the largest amonggroup effect, impacting negatively on both herbivorous reef fish and green turtles, and overall had the largest impact on algal and detrital resources (not shown). Given green turtles' feeding preference on $\operatorname{turf}_{\mathrm{LB}}$, they were the group most impacted by changes in $\operatorname{turf}_{\mathrm{LB}}$ (Fig. 3).

When accounting for the uncertainty around parameters affecting consumption of $\operatorname{turf}_{\mathrm{LB}}, E E$ values of turf $_{\mathrm{LB}}$ in successfully balanced model runs ranged between 0.416 and 0.998 .

The mean TE in the ecosystem as a whole was $4.6 \%$, with a value of $4.5 \%$ for flows originating from primary producers and $4.7 \%$ from the detritus. This low efficiency was due to consumption dominating total system throughput for the lower trophic levels, whereas respiration and flow to detritus dominated the higher trophic levels in the model (Fig. 4). This result is to be expected in a system with low biomass

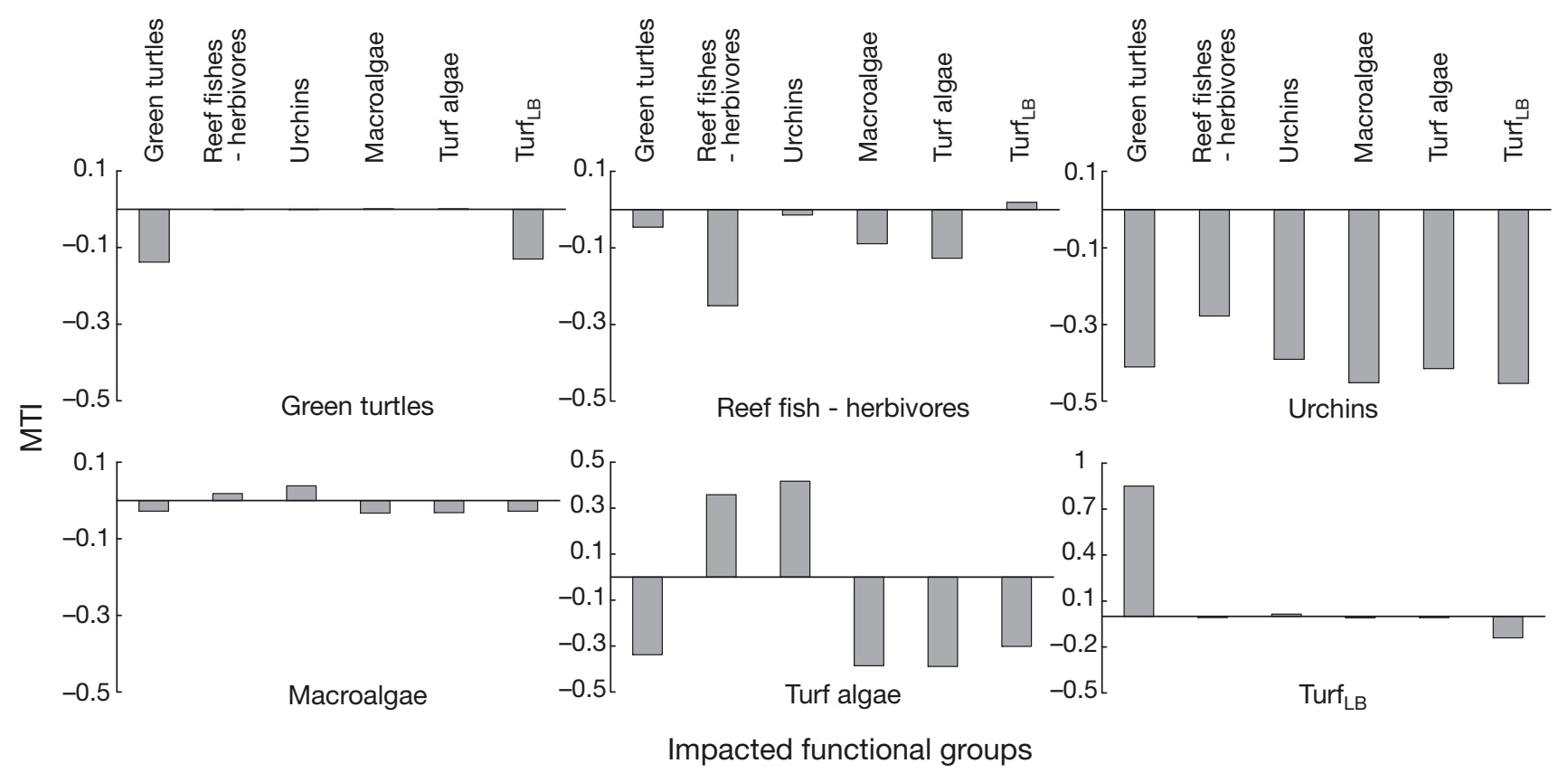

Fig. 3. Mixed trophic impact (MTI) analysis for all herbivores at Kaloko. Impacts of increases in the biomass of a particular group (impacting) on another (impacted), resulting in an increase in the latter's biomass, are recorded as a positive on the $y$-axis. Impacts resulting in a decline of the impacted group are recorded as a negative value. Group names along the upper $x$-axis represent the impacted groups. The impacting group is indicated below individual graphs 


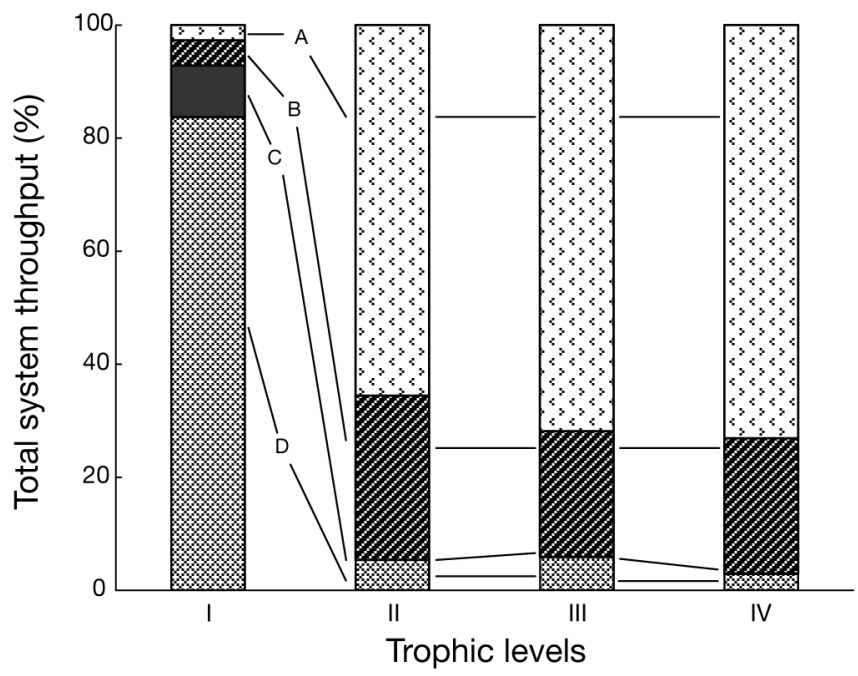

Fig. 4. Fate of total system throughput (A: respiration, B: flow to detritus, C: export, D: consumption by predator) in percentage-per-integer trophic level

at the highest trophic levels. Some upper trophic level species, such as trevally (also locally known as 'ulua' or 'jacks'), are highly vagile. As a consequence, although not being heavily fished for in park waters, their abundance may still be depressed due to high fishing pressure along the remainder of the Kona Coast. Ascendancy was $31.5 \%$ of capacity and relative overhead was $68.5 \%$ (Table 3 ), $46 \%$ of which was attributable to internal flows, indicating that the system contains a number of 'redundant' trophic linkages. These observations are consistent with a system exhibiting relatively high resilience to perturbation with respect to energy flows, or a high system stability sensu Odum (1971).

Net primary productivity was $3895 \mathrm{t} \mathrm{km}^{-2} \mathrm{yr}^{-1}$ and was accompanied by a high flow to the detritus pool (Table 3). Turf algae (including turf LB $_{\text {) }}$ and phytoplankton accounted for 57 and $24 \%$ of total production in the system, or 65 and $27 \%$ of total primary production, respectively. Sea urchins (38\%) were the major contributor to the detrital pool, followed by zooplankton (28\%), while the combined fish groups (mainly herbivores) contributed $11 \%$ of all flows to the detritus. The ratio between primary production and respiration $(P P / R)$ indicates that the system was at a low developmental stage sensu Odum (1969, 1971). This finding was corroborated by the low Finn's cycling index, showing that only a small fraction of the throughput (including detritus) was recycled (6\%; Table 3$)$. The proportion of flows originating from the detritus was $0.27 \%$.

The overall pedigree (i.e. 'quality') index of the model (0.539) was high in comparison to 50 other models for which pedigree values ranged between 0.164 and 0.676 (Morissette 2007).

\section{DISCUSSION}

\section{Description of the Kaloko reef system}

Quantitative descriptions of the flux of matter and energy can provide significant insights into the fundamental structure of ecosystems. The Kaloko system is dominated by primary production $(P P), 27 \%$ of which is contributed by phytoplankton and $65 \%$ by algal turfs, which is slightly lower than other published estimates for primary producers in tropical systems (e.g. Wanders 1976, Adey \& Steneck 1985, Adey \& Goertemiller 1987). The trophic networks at Kaloko were dominated by grazing, with herbivores accounting for $43 \%$ of all living biomass within the system, of which $93 \%$ was sea urchins. This grazer dominance was further highlighted by the high EEs achieved for the main $P P$ functional groups, including phytoplankton. Results from rapid assessment surveys throughout the State confirm that sea urchins in particular, and herbivorous fish, are common on reefs in Hawai'i (Rodgers et al. 2004). In contrast, relatively low EEs of higher trophic level functional groups indicate that the foraging activities of herbivores are not limited by predation pressure, as demonstrated by our analysis of total system throughput (Fig. 4). Indeed, few predators commonly occur in the park, and fewer still have been observed feeding in the park. Therefore, as highlighted by the model's average TE of $4.6 \%$, much lower than the mean of $10 \%$ obtained for various other ecosystems (Christensen \& Pauly 1993), only a small proportion of production is being transferred up the food chain. Comparison between 2 sets of underwater visual census data (E. Brown \& National Park Service unpubl. data) showed a 5-fold increase in piscivore biomass between 2005 and 2007. This inter-annual difference may have been due to real differences between the 2 datasets, possibly reflecting the restrictions on gillnetting in park waters implemented in August 2005. Differences in species biomass and composition may also reflect either variability in survey accuracy for species displaying vagile (e.g. Caranx melampygus) or cryptic behavior (e.g. Gymnothorax flavimarginatus, G. meleagris, Cephalopholis argus), or seasonal changes (Friedlander \& Parrish 1998, Vitousek et al. 2009), as the 2005 and 2007 datasets were collected in April and October, respectively. Future surveys should therefore focus on good intraannual coverage to represent seasonal variation.

Phytoplankton and zooplankton had some of the highest EEs. The waters around Hawai'i are generally oligotrophic (Bienfang et al. 2009), and consequently low biomass of phytoplankton and zooplankton is to be expected. Reef environments along the Kona coast are close to the deep slope of the Pacific and subject to 
strong wave action and currents along the shore (Presto et al. 2007). Therefore, we assumed that zooplanktivores on the reef derive a substantial portion of their diet from open-ocean plankton. We further assumed that ocean plankton contributes to the energy intake of benthic invertebrates and other functional groups that feed on plankton. Experiments should be conducted to ascertain the proportion of ocean plankton in the diet of reef organisms at Kaloko, or other similar systems in Hawai'i.

At $42.54 \mathrm{t} \mathrm{km}^{-2}$, the model's benthic invertebrate (excluding sea urchins) biomass was similar to estimates provided for models in Raja Ampat, Indonesia (51.68 t km²; Ainsworth et al. 2007), and the Great Barrier Reef, Australia (61.41 t km-2; Tudman 2001), but substantially lower than estimates for barrier reefs and fringing reefs in Moorea, French Polynesia (198.26 and 322.8 t km² respectively; Arias-González 1994, Arias-González et al. 1997). Few studies have investigated the composition of benthic invertebrates on reefs, yet they are an important prey for certain groups of reef fish (e.g. Hobson 1974) and can represent an important fishery (Friedlander \& Parrish 1997). Given that benthic invertebrates accounted for $6 \%$ of total system biomass, species composition and their relative contribution to total group biomass of the benthic invertebrate community of Kaloko should be determined.

Sea urchin densities at Kaloko (ca. 5 ind. $\mathrm{m}^{-2}$ for Echinometra mathaei and $<1$ ind. $\mathrm{m}^{-2}$ for all other species) were comparable to sea urchin densities recorded on reefs throughout the State of Hawai'i (Rodgers et al. 2004) and similar to, or lower than, those reported from other reef locations, e.g. 5 to 6.8 ind. $\mathrm{m}^{-2}$ (chiefly E. mathaei and Tripneustes gratilla) at La Réunion (Naim et al. 1997) and 2 to 4 ind. $\mathrm{m}^{-2}$ (Echinometra) in Fiji (Appana \& Vuki 2006). Current sea urchin densities at Kaloko are also comparable to those recorded in the 1970s (Ebert 1971). These similarities suggest that high sea urchin densities are natural and do not represent a release from predation pressure due to increased fishing pressure in the last $30 \mathrm{yr}$, as noted at a number of locations along the coast of Kenya (Muthiga \& McClanahan 1987, McClanahan 1998).

\section{Turtles at carrying capacity}

Green turtles are at carrying capacity at Kaloko based on (1) their biomass estimates and consumption rates, (2) estimates of turf $\mathrm{LB}_{\mathrm{LB}}$ as well as the primary production rates of these algae, and (3) the high degree to which sea urchins feed on the green turtles' main food resource. Balanced model outputs under Ecoranger, taking into account the uncertainty surrounding these input parameters, showed that the $E E$ of $\operatorname{turf}_{\mathrm{LB}}$ could range between 0.416 and 0.998 . Specifically, it reflects the wide range in published biomass and mass-specific productivity rates for turf algae. For example, biomass was found to vary between $230 \mathrm{~g} \mathrm{~m}^{-2}$ ( $\mathrm{T}$. Sauvage pers. comm.) and $600 \mathrm{~g} \mathrm{~m}^{-2}$ (Smith et al. 2001) in Hawai'i alone, $78 \mathrm{~g} \mathrm{~m}^{-2}$ in the Solomon Islands (Albert et al. 2008), and $850 \mathrm{~g} \mathrm{~m}^{-2}$ in the Caribbean (Bruggemann et al. 1994). Even greater ranges in productivity have been recorded for the different algal groups that constitute 'turf,' particularly in relation to depth and seasonal cycles (Payri 2000). An evaluation of algal turf productivity and consumption rates by green turtles at Kaloko would help refine the estimates presented here.

Results from the MTI analysis highlighted the strong competition for the same resource between sea urchins, herbivorous reef fish, and green turtles. Grazing pressure exerted by herbivorous fish does not occur uniformly on a reef. Grazing may be reduced in places where reef structure affords little refuge from predation (Lewis 1986). However, this may not be a significant factor at Kaloko where overall predation pressure is limited due to the low abundance of piscivores. Foraging efficiency may also be reduced on shallower portions of the reef due to relative high wave intensity and potential exposure of animals when water levels are low. We therefore assumed that fish at Kaloko graze chiefly on reef turf algae rather than on turf $_{\text {LB }}$ specifically (Table 2). Recent evidence from the South Pacific demonstrates that few of the fish species previously classified as 'herbivores' are indeed exclusively herbivorous (Choat et al. 2002, Cvitanovic et al. 2007). Many appear to predominantly feed on detritus, only incidentally removing turf from the reef in the process (Crossman et al. 2001, 2005). Data on the extent of algae removed but not consumed are needed to correct our current assumption that all algal material removed by herbivorous fish was ingested. MTI results reflected resource competition between turtles and fish primarily for macroalgae, which appeared 'magnified' as macroalgae biomass overall in the park is low. As sea urchins occur in the shallows (M. Weijerman pers. comm., L. Marrack pers. comm.), probably emerging at night to feed (Mills et al. 2000, Vaitilingon et al. 2003), a small proportion of $\operatorname{turf}_{\mathrm{LB}}$ was included in the echinoids' diet matrix (Table 2). Quantification in the field of this overlap and the extent to which relative densities among the 3 herbivore functional groups may change with time would help refine carrying capacity estimates for green turtles. Clarification of the extent to which sea urchins feed on $\operatorname{turf}_{\mathrm{LB}}$ also has implications for their role in maintaining low algal biomass levels in the face of increased nutrient input associated with urban development activities around the park (see below). 
Observations that Kaloko green turtles appear unusually 'skinny' (Kubis et al. 2008) and exhibit low growth rates (Balazs \& Chaloupka 2004b) compared with turtles at a number of other Hawaiian foraging grounds support input parameters within the range used in our model (Table 1). A key difference between individual foraging sites that may help explain variations in observed growth rates is that green turtles at Kaloko forage on turf, the dominant algal group on the central Kona Coast, whereas other foraging grounds throughout the Hawaiian Archipelago have macroalgae available as forage (Arthur \& Balazs 2008). Until recently, turtles tagged at Kaloko were rarely found outside of park waters, and therefore it is unlikely they were obtaining food from outside the modeled area. However, new observations have indicated a behavioral shift in the green turtles' foraging patterns. Fewer individuals are utilizing the shallow reef area in the summer months than they did prior to ca. 2006 (S. Beavers unpubl. data). More human interactions, resulting from recent increases in visitors to the park, may be partly responsible for this change in behavior (S. Beavers unpubl. data). Greater turtle movement possibly away from Kaloko further strengthens the case for carrying capacity having been reached at the park because of limited available forage.

Turf algae growing on the lava bench close to shore and in the intertidal area were included in the model as a separate functional group, as resident green turtles at Kaloko have been seen to concentrate their grazing on this portion of the park. Such focused foraging behavior may occur for 3 reasons:

(1) By focusing their feeding activities on shallow portions of the reef, individuals exert less effort foraging, as the lava bench supports a highly productive algal mat that can grow unrestricted by space competition with live coral. Were turtles to forage on deeper sections of the reef, for a similar intake of algae, animals would have to roam over wider areas and pick algae from in and around coral heads, resulting in greater energy expenditure. More energy would also have to be expended by animals in having to come to the surface to breathe. Our results, corroborated by local observations of turf algae throughout the park being closely cropped (F. Parrish pers. comm.), indicated that the system was also close to carrying capacity for overall turf algae, making foraging by green turtles in deeper reef sections even less energy efficient. 'True' carrying capacity of turf algae on the reef may actually be realized at lower EE values, because where turf algae are laden with sediment, much of the algae may not be available to grazers.

(2) Green turtles may prefer to forage on the lava bench because of the protection afforded by the shallows against predation by tiger sharks. Sharks are regularly sighted at Kaloko (e.g. see www.state.hi.us/ dlnr/chairpio/HtmlNR/01-46.htm and http://starbulletin. com/2005/07/01/news/index5.html), and a log of necropsies performed on turtles at Kaloko indicates that shark attacks were responsible for the death of 4 turtles since 1992 (obviously, attacks that resulted in the complete ingestion of turtles by sharks cannot be monitored; G. Balazs unpublished data). Thus, the distribution of turtles, and the algae they consume, may be affected by differential vulnerability of green turtles to shark predation in different habitats (Heithaus et al. 2002, 2006). Nutritionally profitable microhabitats at Kaloko also appear to be low risk from a predation perspective.

(3) The repeatedly grazed turf $\mathrm{LB}_{\mathrm{B}}$ may be more palatable to green turtles than algae growing on deeper sections of the reef. The area where turtles tend to aggregate to feed is located close to 'Ai'opio fish trap, an area of considerable groundwater discharge (Johnson et al. 2008). As groundwater is the only conduit for nutrients into the coastal zone, the nutritional content of algae in this specific location may be significantly different from algae on the remainder of the reef.

\section{Potential threats and impacts on natural resources due to urban development}

On many coral reefs near human population centers, benthic community composition has shifted from coraldominated to macroalgae-dominated (Hughes 1994, Hunter \& Evans 1995, McClanahan \& Mangi 2001). These shifts, often termed 'phase shifts' (Done 1992), have been attributed to increased anthropogenic nutrient input (e.g. Lapointe 1997) and/or to reductions in the abundance of herbivores (e.g. Hay 1984b). Studies investigating changes in grazing intensity at sites that have undergone such phase shifts (e.g. Kāne'ohe Bay, Hawai'i), have focused primarily on the role of herbivorous reef fish, and to a lesser extent small, often invertebrate, herbivores (Cheroske et al. 2000) and sea urchins (Hunter \& Evans 1995, Stimson et al. 2001, Smith et al. 2008). As our results clearly demonstrate, future studies need to explicitly consider green turtles because of their important role as herbivores. Their consumption of non-native algae, including Gracilaria salicornia (Russell \& Balazs 2009), abundant at a number of locations across Hawai'i, including Kāne'ohe Bay, further highlights their role in promoting reef resilience.

Ongoing and planned urban development activities, and associated population growth, around Kaloko will likely have significant and diverse impacts on the condition of nearby reefs. Expected impacts include, but are not restricted to: (1) A reduction in groundwater 
discharge quality (i.e. increased nutrient loading), which could lead to increased macroalgal growth and the subsequent deterioration in the health of corals (e.g. Fabricius 2005, Smith \& Smith 2006), particularly if combined with a reduction in the urchin population; and (2) An increase in fishing pressure and a resulting decrease in the herbivorous fish population, which could lead to an increase in the abundance of macroalgae (Stimson et al. 2001, Williams et al. 2007). Based on our findings, some key points emerge that should be taken into account if dynamic simulations of various 'impact scenarios' are run in the future.

Increased nutrient input and higher fishing pressure may lead to an increase in the proportion of macroalgal cover at Kaloko and potential forage for resident herbivores. In 2008, the NPS initiated a long-term marine water quality monitoring program (quarterly sampling), which includes optical chlorophyll sampling. Additionally, plans are underway through a partnership between the NPS and the US Geological Survey to use stable isotope tracers to identify sources of nutrient inputs to park groundwater. The NPS, in partnership with the University of Hawai'i at Hilo, recently also initiated a pilot fisheries harvest monitoring program to identify and quantify fishing pressure within the park; this should be a long-term initiative. Nutrient levels and fisheries' catch time series in conjunction with regular monitoring of algal cover within the different habitats at Kaloko, and the Ecopath model developed herein, may help to determine the impacts of such changes at the ecosystem level. Based on our model, we would expect the following responses to 2 scenarios:

(1) Increased nutrient delivery to the reef system without changes in fishing pressure. Under conditions of nutrient enrichment and intense herbivory, algal productivity may be high while biomass remains low (Hatcher \& Larkum 1983). Our results demonstrate that current rates of herbivory, sea urchins, fish, and green turtles maintain all algal groups closely cropped and may therefore be able to consume increases in algal production. This grazing disturbance in turn limits the establishment of macroalgae (Lewis 1986, Williams et al. 2001, Paddack et al. 2006), implying that the current system is relatively resilient to change (as indicated by Kaloko's O/C ratio). Indeed, it is the synergy of these 3 herbivorous functional groups that makes Kaloko an interesting case study. The 'redundancy' in herbivory at Kaloko stands in contrast to areas of the Caribbean, where sea urchin biomass remains low 20 yr after the region-wide loss of the key echinoid herbivore to disease (Mumby et al. 2006b), and where, due to high fishing pressure, the ability of herbivorous fish to maintain a high proportion of reef area free of macroalgae may be limited. Some evidence suggests that even robust herbivorous reef fish populations may be capable of maintaining only 50 to $65 \%$ of the substratum in a cropped state (Williams et al. 2001). Although herbivorous fish may be capable of increasing their grazing rates and/or population sizes in response to higher algal production, evidence for this in the published literature is limited (McClanahan et al. 1999, Williams et al. 2001, Garpe et al. 2006). Moreover, herbivorous reef fish, with the exception of Naso spp. (Choat et al. 2002), all prefer turf algae over other algal resources, and frequently avoid macroalgae (Bellwood \& Choat 1990, Bruggemann et al. 1994). Green turtles and sea urchins, on the other hand, commonly feed on macroalgae, highlighting their respective roles in maintaining reef resilience (Nystrom 2006).

(2) Increased nutrient delivery to the reef system with increase in fishing pressure. Herbivorous fish and sea urchins play different and complementary roles in maintaining low algal cover on reefs in the face of disturbance (e.g. Morrison 1988). Under a scenario of higher fishing pressure, model parameterization indicates that sea urchin abundance may increase as a direct response to more abundant forage on the reef and reduced predation pressure due to harvesting of the urchins' predators. Sea urchins, when abundant, can have a considerable impact on benthic ecology. Healthy populations of sea urchins have been associated with reductions in macroalgal cover and increased coral recruitment (Edmunds \& Carpenter 2001, Carpenter \& Edmunds 2006). Typically, sea urchins will consume a greater diversity of algae than herbivorous reef fish and, as such, they will be more effective than the latter at controlling algal growth in the event of increased nutrient levels. Alternatively, as some species of echinoids can remove a large amount of calcium carbonate while foraging (Hutchings 1986, Carreiro-Silva \& McClanahan 2001), an overabundance of sea urchins can lead to rapid erosion of the reef framework (McClanahan \& Kurtis 1991, Bak 1994, Mapstone et al. 2007). For example, Echinothrix diadema and Echinometra mathaei typically erode $20 \%$ of the calcium carbonate accreted (Carreiro-Silva \& McClanahan 2001). However, the relative contributions of grazing and bioerosion are species-dependent. Tripneustes gratilla predominantly browses on macroalgae, suggesting that this species would have less of an impact on the reef framework (Mills et al. 2000).

Currently, sea urchin densities are greatest in the shallows, while reef fish dominate grazing processes at depth (F. Parrish \& M. Weijermann pers. comm.). Higher fishing pressure may reduce fish grazing intensity on deeper reef sections. In response to reduced predation, competition, and increased forage availability, sea urchins could increase in abundance at greater depths. Similarly, green turtles may also displace some of their foraging activities to deeper reef areas to take 
advantage of increased algal biomass (i.e. profitable, high-risk microhabitat sensu Heithaus et al. 2007). Increases in algal biomass would further be exacerbated if mixing carries nutrients to those deeper sections of reef.

\section{CONCLUSIONS}

Our model evaluates the trophic linkages and flows on a Hawaiian near-shore reef. Our study is unique in its detailed analysis of herbivory levels and its focus on the role of herbivores to determine whether a given functional group, in this instance green turtles, is at carrying capacity. Integration of additional quantitative field data on biomass, distribution, consumption rates, and diet selection of the 3 herbivore functional groups would clarify the proportion and type of algae consumed by sea urchins and green turtles versus herbivorous fish on a Hawaiian reef and further elucidate their respective roles in, and contribution to, reef resilience (Nystrom \& Folke 2001, Bellwood et al. 2004).

Acknowledgements. This study was supported by funding provided by the NOAA National Marine Fisheries Service and the Disney Wildlife Conservation fund. C.W., V.C., and D.P. also acknowledge support from the Sea Around Us Project, a scientific collaboration between the Pew Environmental Group and The University of British Columbia. Thanks to J. Polovina for help in getting this project off the ground. R. Most and the National Park Service are acknowledged for facilitating many aspects of our work and valuable input throughout the study. M. Rice and students of the Hawaii Preparatory Academy (Kamuela, Hawaii) are acknowledged for their considerable help to G.B. in ocean-capture field work collecting data on green turtles. We are indebted to T. Work of the US Geological Survey National Wildlife Health Center, Honolulu Field Station, for allowing the use of turtle necropsy findings relevant to turtle body condition. K. Benoit-Bird, P. Bienfang, E. Brown, M. Deagle, R. Hoover, H. Jessop, M. Landry, L. Marrack, C. Payri, T. Sauvage, J. Smith, C. Squair, K. Uyehara, S. Waddington, M. Weijerman, and T. Wurth are gratefully acknowledged for invaluable feedback, advice, and assistance during the development of the model, and/or the kind provision of often unpublished data. We also thank F. Parrish for discussions pertaining to model development; and M. Bailey for drawing illustrations of species representative of functional groups. Special gratitude is extended to B. Hunt for stimulating discussions, assistance on all zooplankton and phytoplankton aspects of the model. The revised manuscript benefited from the comments of J. Alder, B. Hunt, M. Coll, B. Klinkenberg, F. Parrish, 3 anonymous reviewers and the editors.

\section{LITERATURE CITED}

Adey W, Goertemiller T (1987) Coral reef algal turfs: master producers in nutrient poor seas. Phycologia 26:374-386

Adey W, Steneck RS (1985) Highly productive eastern Caribbean reefs: synergistic effects of biological and chemical, physical, and geological factors. In: Reaka ML (ed) The ecology of coral reefs symposia series for undersea research. NOAA, Rockville, MD, p 163-187

Ainsworth C, Varkey D, Pitcher T (2007) Ecosystem simulation models for the Bird's Head Seascape, Papua, fitted to data. In: Pitcher T, Ainsworth C, Bailey M (eds) Ecological and economic analyses of marine ecosystems in the Bird's Head Seascape, Papua, Indonesia. Fisheries Centre, Vancouver, BC, p 6-174

> Albert S, Udy J, Tibbetts IR (2008) Responses of algal communities to gradients in herbivore biomass and water quality in Marovo Lagoon, Solomon Islands. Coral Reefs $27: 73-82$

Allen RR (1971) Relation between production and biomass. J Fish Res Board Can 28:1573-1581

Appana SD, Vuki VC (2006) Foraging behavior, substrate preference and influence of Echinometra sp. A on the carbonate budget of Nukubuco Reef, Fiji Islands. Micronesica 38:191-205

Arias-González JE (1994) Trophic balance of a reef ecosystem (Tiahura-Moorea-French Polynesia). C R Acad Sci Serie III Sci Vie 317:1143-1150

Arias-González JE, Delesalle B, Salvat B, Galzin R (1997) Trophic functioning of the Tiahura reef sector, Moorea Island, French Polynesia. Coral Reefs 16:231-246

Arthur KE, Balazs GH (2008) A comparison of immature green turtle (Chelonia mydas) diets among seven sites in the Main Hawaiian Islands. Pac Sci 62:205-217

> Bak RPM (1994) Sea urchin bioerosion on coral reefs: place in the carbonate budget and relevant variables. Coral Reefs 13:99-103

Balazs GH (1980) Synopsis of biological data on the green turtle in the Hawaiian Islands. NOAA-TM-NMFS-SWFC 7. NOAA, National Marine Fisheries Service, Honolulu, HI

> Balazs GH, Chaloupka M (2004a) Thirty-year recovery trend in the once depleted Hawaiian green sea turtle stock. Biol Conserv 117:491-498

Balazs GH, Chaloupka M (2004b) Spatial and temporal variability in somatic growth of green sea turtles (Chelonia mydas) resident in the Hawaiian Archipelago. Mar Biol 145:1043-1059

Balazs GH, Chaloupka M (2006) Recovery trend over 32 years at the Hawaiian green turtle rookery of French Frigate Shoals. Atoll Res Bull 543:147-158

Beets J, Brown E, Friedlander A (2010) Inventory of marine vertebrate species and fish-habitat utilization patterns in coastal waters off four National Parks in Hawai'i. Pacific Cooperative Studies Unit Tech Rep 168. Department of Botany, University of Hawai'i at Mānoa, Honolulu, HI

Bellwood DR, Choat JH (1990) A functional analysis of grazing in parrotfishes (family Scaridae) - the ecological implications. Environ Biol Fishes 28:189-214

Bellwood DR, Hughes TP, Folke C, Nystrom M (2004) Confronting the coral reef crisis. Nature 429:827-833

Bienfang P, De Carlo EH, Christopher S, DeFelice S, Moeller P (2009) Trace element concentrations in coastal Hawaiian waters. Mar Chem 113:164-171

Bjorndal KA (1980) Nutrition and grazing behavior of the green turtle, Chelonia mydas. Mar Biol 56:147-154

Bjorndal KA, Bolten AB, Chaloupka MY (2000) Green turtle somatic growth model: evidence for density dependence. Ecol Appl 10:269-282

Brainard R, Friedlander A, Gulko D, Hunter C, Kelty R, Maragos J (2002) Status of coral reefs in the Hawaiian Archipelago. In: Wilkinson C (ed) Status of coral reefs. Australian Institute of Marine Science, Townsville, p 238-250 
Bruggemann JH, Vanoppen MJH, Breeman AM (1994) Foraging by the stoplight parrotfish Sparisoma viride. I. Food selection in different socially determined habitats. Mar Ecol Prog Ser 106:41-55

Burkepile DE, Hay ME (2006) Herbivore vs. nutrient control of marine primary producers: context-dependent effects. Ecology 87:3128-3139

> Carpenter RC, Edmunds PJ (2006) Local and regional scale recovery of Diadema promotes recruitment of scleractinian corals. Ecol Lett 9:271-280

Carreiro-Silva M, McClanahan TR (2001) Echinoid bioerosion and herbivory on Kenyan coral reefs: the role of protection from fishing. J Exp Mar Biol Ecol 262:133-153

> Chaloupka M, Balazs G (2007) Using Bayesian state-space modelling to assess the recovery and harvest potential of the Hawaiian green sea turtle stock. Ecol Model 205: 93-109

> Chaloupka M, Bjorndal KA, Balazs GH, Bolten AB and others (2008) Encouraging outlook for recovery of a once severely exploited marine megaherbivore. Glob Ecol Biogeogr 17:297-304

> Cheroske AG, Williams SL, Carpenter RC (2000) Effects of physical and biological disturbances on algal turfs in Kaneohe Bay, Hawaii. J Exp Mar Biol Ecol 248:1-34

> Choat JH, Clements KD, Robbins WD (2002) The trophic status of herbivorous fishes on coral reefs. I. Dietary analyses. Mar Biol 140:613-623

> Christensen V (1995) Ecosystem maturity — towards quantification. Ecol Model 77:3-32

Christensen V (2008) Ecopath with Ecosim: linking fisheries and ecology. In: Jørgensen SE, Chon TS, Recknagel FA (eds) Handbook of ecological modelling, network and informatics. WIT Press, Billerica, MA, p 55-70

> Christensen V, Pauly D (1992) ECOPATH II - a software for balancing steady-state ecosystem models and calculating network characteristics. Ecol Model 61:169-185

Christensen V, Pauly D (eds) (1993) Trophic models of aquatic ecosystems, Vol 26. ICLARM, Manila

Christense V, Pauly D (1998) Changes in models of aquatic ecosystems approaching carrying capacity. Ecol Appl 8: S104-S109

> Christensen V, Walters C (2004) Ecopath with Ecosim: methods, capabilities and limitations. Ecol Model 172:109-139

Christensen V, Walters CJ, Pauly D (2005) Ecopath with Ecosim: a user's guide. Fisheries Centre, University of British Columbia, Vancouver, BC

> Crossman DJ, Choat JH, Clements KD, Hardy T, McConochie $\mathrm{J}$ (2001) Detritus as food for grazing fishes on coral reefs. Limnol Oceanogr 46:1596-1605

Crossman DJ, Choat JH, Clements KD (2005) Nutritional ecology of nominally herbivorous fishes on coral reefs. Mar Ecol Prog Ser 296:129-142

Cvitanovic C, Fox RJ, Bellwood DR (2007) Herbivory by fishes on the Great Barrier Reef: a review of knowledge and understanding. Report to the Marine and Tropical Sciences Research Facility. Reef and Rainforest Research Centre Limited, Cairns

DeVerse K (2006) Appendix A: Kaloko-Honokōhau National Historical Park resource overview. In: HaySmith L, Klasner FL, Stephens SH, Dicus GH (eds) Pacific Island Network vital signs monitoring plan. Natural resource report NPS/PACN/NRR-2006/003, National Park Service, Fort Collins, CO, p 1-21

Done T (1992) Phase shifts in coral reef communities and their ecological significance. Hydrobiologia 247:121-132

Doty MS (1961) Acanthophora, a possible invader of the marine flora of Hawaii. Pac Sci 15:547-552
Dutton P, Balazs G, LeRoux R, Murakawa S, Zarate P, Martínez L (2008) Composition of Hawaiian green turtle foraging aggregations: mtDNA evidence for a distinct regional population. Endang Species Res 5:37-44

Ebert TA (1971) Preliminary quantitative survey of echinoid fauna of Kealakekua and Honaunau bays, Hawaii. Pac Sci 25:112-131

Edmunds PJ, Carpenter RC (2001) Recovery of Diadema antillarum reduces macroalgal cover and increases abundance of juvenile corals on a Caribbean reef. Proc Natl Acad Sci USA 98:5067-5071

Fabricius KE (2005) Effects of terrestrial runoff on the ecology of corals and coral reefs: review and synthesis. Mar Pollut Bull 50:125-146

Friedlander AM, Parrish JD (1997) Fisheries harvest and standing stock in a Hawaiian bay. Fish Res 32:33-50

Friedlander AM, Parrish JD (1998) Temporal dynamics of fish communities on an exposed shoreline in Hawaii. Environ Biol Fishes 53:1-18

Friedlander A, Aeby G, Brainard R, Brown E and others (2008) The state of coral reef ecosystems of the Main Hawaiian Islands. In: Waddell JE, Clarke AM (eds) State of coral reef ecosystems of the United States and Pacific Freely Associated States: 2008. NOAA Tech Memo NOS NCCOS 73. NOAA/NCCOS Center for Coastal Monitoring and Assessment's Biogeography Team, Silver Spring, MD, p 219-261

Funtowicz SO, Ravetz JR (1990) Uncertainty and quality in science for policy. Kluwer Academic Publishers, Dordrecht

Gardner TA, Cote IM, Gill JA, Grant A, Watkinson AR (2003) Long-term region-wide declines in Caribbean corals. Science 301:958-960

Garpe KC, Yahya SAS, Lindahl U, Öhman MC (2006) Longterm effects of the 1998 coral bleaching event on reef fish assemblages. Mar Ecol Prog Ser 315:237-247

Gibbs AE, Cochran SA, Logan JB, Grossman EE (2007) Benthic habitats and offshore geological resources of KalokoHonokōhau National Historical Park, Hawai'i. Scientific Investigations Report 2006-5256. US Geological Survey, Santa Cruz, CA. (Available at http://pubs.usgs.gov/sir/ 2006/5256/)

Grigg RW (1994) Effects of sewage discharge, fishing pressure and habitat complexity on coral ecosystems and reef fishes in Hawai'i. Mar Ecol Prog Ser 103:25-34

- Hatcher BG, Larkum AWD (1983) An experimental analysis of factors controlling the standing crop of the epilithic algal community on a coral reef. J Exp Mar Biol Ecol 69:61-84

Hay ME (1981) Spatial patterns of grazing intensity on a Caribbean barrier reef: herbivory and algal distribution. Aquat Bot 11:97-109

Hay ME (1984a) Patterns of fish and urchin grazing on Caribbean coral reefs: Are previous results typical? Ecology 65:446-454

> Hay ME (1984b) Predictable spatial escapes from herbivory: How do these affect the evolution of herbivore resistance in tropical marine communities? Oecologia 64:396-407

> Heck KL Jr, Valentine JF (2006) Plant-herbivore interactions in seagrass meadows. J Exp Mar Biol Ecol 330:420-436

> Heithaus MR, Frid A, Dill LM (2002) Shark-inflicted injury frequencies, escape ability, and habitat use of green and loggerhead turtles. Mar Biol 140:229-236

Heithaus MR, Hamilton IM, Wirsing AJ, Dill LM (2006) Validation of a randomization procedure to assess animal habitat preferences: microhabitat use of tiger sharks in a seagrass ecosystem. J Anim Ecol 75:666-676 
Heithaus MR, Frid A, Wirsing AJ, Dill LM and others (2007) State-dependent risk-taking by green sea turtles mediates top-down effects of tiger shark intimidation in a marine ecosystem. J Anim Ecol 76:837-844

Heymans JJ (2003) Comparing the Newfoundland-southern Labrador marine ecosystem models using information theory. In: Heymans JJ (ed) Ecosystem models of Newfoundland and southeastern Labrador: additional information and analyses for 'back to the future', Vol 11(5). Fisheries Centre Research Reports, Vancouver, BC, p 62-71

Hobson ES (1974) Feeding relationships of teleostean fishes on coral reefs in Kona, Hawaii. Fish Bull 72:915-1031

Hughes TP (1994) Catastrophes, phase shifts and large-scale degradation of a Caribbean coral reef. Science 265: 1547-1551

Hunter C, Evans C (1995) Coral reefs in Kaneohe Bay, Hawaii: two centuries of western influence and two decades of data. Bull Mar Sci 57:501-515

Hutchings PA (1986) Biological destruction of coral reefs - a review. Coral Reefs 4:239-252

Johnson AG, Glenn C, Burnett WC, Peterson RN, Lucey P (2008) Aerial infrared imaging reveals large nutrient-rich groundwater inputs to the ocean. Geophys Res Lett 35:L15606, doi:15610.11029/12008GL034574

Kubis S, Work T, Murakawa SKK, Balazs GH (2008) An alternative method for assessing body condition of Hawaiian green turtles. In: Proc 27th Annu Symp Sea Turtle Biol Conserv, Myrtle Beach, SC, p 21-22

Lapointe BE (1997) Nutrient thresholds for eutrophication and macroalgal blooms on coral reefs in Jamaica and southeast Florida. Limnol Oceanogr 42:1119-1131

Lessios HA (1988) Mass mortality of Diadema antillarum in the Caribbean: What have we learned? Annu Rev Ecol Syst 19:371-393

Lewis S (1986) The role of herbivorous fishes in the organisation of a Caribbean reef community. Ecol Monogr 56: 183-200

Littler MM, Littler DS (2007) Assessment of coral reefs using herbivory/nutrient assays and indicator groups of benthic primary producers: a critical synthesis, proposed protocols, and critique of management strategies. Aquat Conserv 17:195-215

Mapstone BD, Andrew NL, Chancerelle Y, Salvat B (2007) Mediating effects of sea urchins on interactions among corals, algae and herbivorous fish in the Moorea lagoon, French Polynesia. Mar Ecol Prog Ser 332:143-153

Marrack L, Beavers S, Weijerman M (2009) Baseline assessment of the coral reef habitat adjacent to the shores of Kohanaiki development in Kaloko-Honokōhau National Historical Park. Cooperative Ecosystem Studies Unit, University of Hawai'i at Hilo, Hilo and Kaloko-Honokōhau National Park, Kailua-Kona, HI

McClanahan TR (1998) Predation and the distribution and abundance of tropical sea urchin populations. J Exp Mar Biol Ecol 221:231-255

McClanahan TR, Kurtis JD (1991) Population regulation of the rock-boring sea urchin Echinometra mathaei (Deblainville). J Exp Mar Biol Ecol 147:121-146

McClanahan TR, Mangi S (2001) Coral and algal response to the 1998 El Niño coral bleaching and mortality on Kenya's southern reef lagoons. OceanDocs E-Repository of Ocean Publications. Available at http://www.oceandocs.org/ handle/1834/482/

McClanahan TR, Hendrick V, Rodrigues MJ, Polunin NVC (1999) Varying responses of herbivorous and invertebratefeeding fishes to macroalgal reduction on a coral reef. Coral Reefs 18:195-203
McCutcheon S, McDermid K, Balazs G (2003) A nutritional analysis of the turf algal diet and fecal pellets of the green turtle, Chelonia mydas. J Phycol 39:41

McDermid KJ, Stuercke B, Balazs GH (2007) Nutritional composition of marine plants in the diet of the green sea turtle (Cholonia mydas) in the Hawaiian Islands. Bull Mar Sci 81:55-71

Mills SC, Peyrot-Clausade M, Fontaine MF (2000) Ingestion and transformation of algal turf by Echinometra mathaei on Tiahura fringing reef (French Polynesia). J Exp Mar Biol Ecol 254:71-84

Morissette L (2007) Complexity, cost and quality of ecosystem models and their impact on resilience: a comparative analysis, with emphasis on marine mammals and the Gulf of St. Lawrence. PhD thesis, University of British Columbia, Vancouver, BC

Morrison D (1988) Comparing fish and urchin grazing in shallow and deeper coral reef algal communities. Ecology 69:1367-1382

Mortimer JA (1981) The feeding ecology of the west Caribbean green turtle (Chelonia mydas) in Nicaragua. Biotropica 13:49-58

Mumby PJ, Dahlgren CP, Harborne AR, Kappel CV and others (2006a) Fishing, trophic cascades, and the process of grazing on coral reefs. Science 311:98-101

Mumby PJ, Hedley JD, Zychaluk K, Harborne AR, Blackwell PG (2006b) Revisiting the catastrophic die-off of the urchin Diadema antillarum on Caribbean coral reefs: fresh insights on resilience from a simulation model. Ecol Modell 196:131-148

> Muthiga NA, McClanahan TR (1987) Population changes of a sea urchin (Echinometra mathaei) on an exploited fringing reef. Afr J Ecol 25:1-8

Naim O, Cuet P, Letourneur Y (1997) Experimental shift in benthic community structure. In: Proc 8th Int Coral Reef Symp:1873-1878

Nystrom M (2006) Redundancy and response diversity of functional groups: implications for the resilience of coral reefs. Ambio 35:30-35

> Nystrom M, Folke C (2001) Spatial resilience of coral reefs. Ecosystems 4:406-417

Odum EP (1969) The strategy of ecosystem development. Science 164:262-270

Odum EP (1971) Fundamentals of ecology. Saunders, Philadelphia, PA

$>$ Ogden JC, Lobel PS (1978) The role of herbivorous fishes and urchins in coral reef communities. Environ Biol Fishes 3: $49-63$

Oki DS, Tribble GW, Souza WR, Bolke EL (1999) Groundwater resources in Kaloko-Honokōhau National Historical Park, Island of Hawaii, and numerical simulation of the effects of ground-water withdrawals. Water Res Invest Rep 99-4070, US Geological Survey \& National Park Service, Honolulu, HI

Paddack MJ, Cowen RK, Sponaugle S (2006) Grazing pressure of herbivorous coral reef fishes on low coral-cover reefs. Coral Reefs 25:461-472

Parrish J, Smith G, Norris J (1990) Resources of the marine waters of Kaloko-Honokōhau National Historical Park. Tech Rep 74. Cooperative National Park Resources Study Unit, Department of Botany, University of Hawaii, Honolulu, HI

Pauly D (1980) On the interrelationships between natural mortality, growth parameters, and mean environmental temperature in 175 fish stocks. J Cons Int Explor Mer 39:175-192 
Pauly D, Christensen V (1995) Primary production required to sustain global fisheries. Nature 374:255-257

Pauly D, Christensen V (2002) Ecosystem models. In: Hart PJ, Reynolds JD (eds) Handbook of fish biology and fisheries, Vol 2. Blackwell Publishing, Oxford, p 211-227

Pauly D, Christensen V, Walters C (2000) Ecopath, Ecosim, and Ecospace as tools for evaluating ecosystem impact of fisheries. ICES J Mar Sci 57:697-706

Payri C (2000) Production primaire et calcification des algues benthiques en milieu corallien. Oceanis 26:427-463

Paytan A, Shellenbarger GG, Street JH, Gonneea ME, Davis K, Young MB, Moore WS (2006) Submarine groundwater discharge: an important source of new inorganic nitrogen to coral reef ecosystems. Limnol Oceanogr 51: 343-348

Plaganyi EE (2007) Models for an ecosystem approach to fisheries. FAO Fisheries Tech Publ No 477, Rome

Plaganyi EE, Butterworth DS (2004) A critical look at the potential of Ecopath with Ecosim to assist in practical fisheries management. Afr J Mar Sci 26:261-287

Polovina JJ (1984) Model of a coral-reef ecosystem. I. The Ecopath model and its application to French Frigate Shoals. Coral Reefs 3:1-11

Presto MK, Storlazzi CD, Logan JB, Grossman EE (2007) Submarine groundwater discharge along the coast of KalokoHonokōhau National Historic Park, Hawai'i. Part I: Time series measurements of currents, waves and water properties. US Geological Survey open file report. Available at http://pubs.usgs.gov/of/2007/1310

Rodgers Ku, Jokiel PL, Brown EK (2004) Rapid assessment of Kaloko-Honokōhau and Pu'uhonua o Honaunau, west Hawai'i. Hawaii Coral Reef Assessment and Monitoring Program (CRAMP), Hawaii Institute of Marine Biology, Kāne'ohe, HI

Russell DJ (1992) The ecological invasion of Hawaiian reefs by two marine red algae, Acanthophora spicifera (Vahl) Boerg. and Hypnea musciformis (Wulfen) J. Ag. and their association with two native species Laurencia nidifica J. Ag. and Hypnea cervicornis J. Ag. ICES Mar Sci Symp 194:110-125

Russell DJ, Balazs GH (1994) Colonization by the alien marine alga Hypnea musciformis (Wulfen) J Ag (Rhodophyta, Gigartinales) in the Hawaiian Islands and its utilization by the green turtle, Chelonia mydas L. Aquat Bot 47: $53-60$

Russell DF, Balazs GH (2009) Dietary shifts by green turtles (Chelonia mydas) in the Kane'ohe Bay region of the Hawaiian Islands: a 28-year study. Pac Sci 63:181-192

Smith MK (1993) An ecological perspective on inshore fisheries in the main Hawaiian islands. Mar Fish Rev 55:34-49

Smith CM, Smith JE (2006) Algal blooms in north Kihei: an assessment of patterns and processes relating nutrient dynamics to algal abundance. Report for the city and county of Maui, HI. Available at www.nceas.ucsb.edu/ jsmith/Smith_Maui_Final_Report.pdf

Smith JE, Smith CM, Hunter CL (2001) An experimental analysis of the effects of herbivory and nutrient enrichment on benthic community dynamics on a Hawaiian reef. Coral Reefs 19:332-342

Smith JE, Conklin EJ, Smith CM, Hunter CL (2008) Fighting algae in Kaneohe Bay. Science 319:157-158

Stimson J, Larned ST, Conklin E (2001) Effects of herbivory, nutrient levels, and introduced algae on the distribution and abundance of the invasive macroalga Dictyosphaeria cavernosa in Kaneohe Bay, Hawaii. Coral Reefs 19: 343-357
Thayer GW, Bjorndal KA, Ogden JC, Williams SL, Zieman JC (1984) Role of larger herbivores in seagrass communities. Estuaries 7:351-376

Tissot BN, Walsh WJ, Hallacher LE (2004) Evaluating effectiveness of a marine protected area network in west Hawai'i to increase productivity of an aquarium fishery. Pac Sci 58:175-188

Tissot BN, Walsh WJ, Hixon MA (2009) Hawaiian Islands marine ecosystem case study: ecosystem- and communitybased management in Hawaii. Coast Manag 37:255-273

Tudman PD (2001) Modelling the trophic effects of fishing on a mid-shelf coral reef of the central Great Barrier Reef. BSc thesis, James Cook University, Brisbane

Ulanowicz RE (1997) Ecology: the ascendent perspective. Columbia University Press, New York, NY

Ulanowicz RE, Puccia CJ (1990) Mixed trophic impacts in ecosystems. Coenoses 5:7-16

Vaitilingon D, Rasolofonirina R, Jangoux M (2003) Feeding preferences, seasonal gut repletion indices, and diel feeding patterns of the sea urchin Tripneustes gratilla (Echinodermata: Echinoidea) on a coastal habitat off Toliara (Madagascar). Mar Biol 143:451-458

Valentine JF, Heck KL, Cinkovich AM (2002) Impacts of seagrass food webs on marine ecosystems: a need for a broader perspective. Bull Mar Sci 71:1361-1368

Vitousek S, Barbee MM, Fletcher CH, Richmond BM, Genz AS (2009) Pu'ukoholā Heiau National Historic Site and Kaloko-Honokōhau Historical Park, Big Island of Hawai'i. Coastal Hazard Analysis Report. NPS Geologic Resources Division, Honolulu, HI

Wabnitz CCC (2010) Sea turtle conservation and ecosystembased management with a focus on green turtles (Chelonia mydas) and seagrass beds. $\mathrm{PhD}$ thesis, University of British Columbia, Vancouver, BC

Waddell JE, Clarke AM (eds) (2008) The state of coral reef ecosystems of the United States and Pacific Freely Associated States: 2008. NOAA Tech Memo NOS NCCOS 73. NOAA/NCCOS Center for Coastal Monitoring and Assessment's Biogeography Team, Silver Spring, MD

Walters CJ, Martell SJD (2004) Fisheries ecology and management. Princeton University Press, Princeton, NJ

Walters C, Christensen V, Pauly D (1997) Structuring dynamic models of exploited ecosystems from trophic mass-balance assessments. Rev Fish Biol Fish 7:139-172

> Wanders JBW (1976) The role of benthic algae in the shallow reef of Curaçao (Netherlands Antilles). I. Primary productivity in the coral reef. Aquat Bot 2:235-270

Weijerman M, Beavers S, Marrack L, Most R (2009) Baseline assessment of the coral reef habitat in Kaloko-Honokōhau National Historical Park adjacent to the proposed harbor expansion and development, Kona Kai Ola. Cooperative Ecosystem Studies Unit, University of Hawai'i at Mānoa, Honolulu, HI, US Geological Survey, Honolulu, and US National Park Service, Kaliua-Kona, HI

> Williams ID, Polunin NVC, Hendrick VJ (2001) Limits to grazing by herbivorous fishes and the impact of low coral cover on macroalgal abundance on a coral reef in Belize. Mar Ecol Prog Ser 222:187-196

Williams ID, Walsh WJ, Sparks RT, Polhemus DA (2007) The slippery slope to slime: invasive alien algae, coral to macroalgal shifts, and the scope for increasing herbivorous fish stocks as a control mechanism. State of Hawai'i Division of Aquatic Resources, Honolulu, HI

Williams ID, Walsh WJ, Schroeder RE, Friedlander AM, Richards BL, Stamoulis KA (2008) Assessing the importance of fishing impacts on Hawaiian coral reef fish assem- 
blages along regional-scale human population gradients. Environ Conserv 35:261-272

Witzell WN (1994) The origin, evolution, and demise of the U.S. sea turtle fisheries. Mar Fish Rev 56:8-23

Work T (2007) Diagnostic case report, Hilton Waikaloa. US Geological Survey, Biological Resources Division, National Wildlife Health Center, Honolulu Field Station, Honolulu, HI

Work T (2008a) Diagnostic case report, Kaloko Honokōhau NHP. US Geological Survey, Biological Resources Division, National Wildlife Health Center, Honolulu Field Station, Honolulu, HI

Editorial responsibility: Hans Heinrich Janssen, Oldendorf/Luhe, Germany
Work T (2008b) Diagnostic case report, Pu'uhonua O Honaunau NHP. US Geological Survey, Biological Resources Division, National Wildlife Health Center, Honolulu Field Station, Honolulu, HI

Wulff F, Field JG, Mann KH (eds) (1989) Network analysis in marine ecology: methods and applications. Coastal and estuarine studies, Vol 32. Springer Verlag, Berlin

Zeller D, Booth S, Pauly D (2005) Reconstruction of coral reef and bottom fisheries catches for US flag island areas in the western Pacific, 1950-2002. Final report to the Western Pacific Regional Fishery Management Council. Fisheries Centre, Vancouver, BC

Submitted: January 18, 2010; Accepted: September 22, 2010 Proofs received from author(s): November 26, 2010 